\title{
EVALUASI KATALOG ONLINE PERPUSTAKAAN MENGGUNAKAN PENDEKATAN SALTON AND MCGILL
}

\author{
Fitriana Tjiptasari \\ Universitas Negeri Yogyakarta \\ e-mail: fitriana@uny.ac.id
}

\begin{abstract}
Abstrak
Kajian ini bertujuan untuk evaluasi katalog online perpustakaan FIP UNY dalam perspektif manajemen dan pengguna perpustakaan menggunakan pendekatan Salton and McGill. Pendekatan penelitian yang digunakan adalah kualitatif, dengan jenis penelitian deskriptif-analitis. Data yang digunakan adalah data primer dan data sekunder. Hasil kajian menunjukkan bahwa 1) Nilai recall menunjukkan angka 30.61\%, sedangkan nilai precision menunjukkan angka $75.92 \%$ untuk subjek pendidikan anak, dengan penggunaan pada simple search dan advanced search. 2) Sistem mampu menemukan informasi yang dibutuhkan dalam kurun waktu 0,4 detik. 3) Pada poin upaya pengguna, belum ada modul khusus yang disediakan untuk memudahkan pengguna dalam mengakses katalog online. Terutama pada bagian menu pengguna, di mana belum ada menu HELP, tentang tata cara menelusur. Perpustakaan hanya menyediakan fasilitas "Live Chat" dan "Ask Librarian". 4) Tampilan katalog online sesuai dengan standar SLiMS Meranti. Kendala pengguna adalah apabila pengguna tidak menekan menu "detil cantuman", maka pengguna tidak akan mengetahui keberadaan koleksi yang tersebar di tiga kampus. 5) Koleksi yang dihimpun perpustakaan FIP masih didominasi oleh buku teks.
\end{abstract}

Kata Kunci: katalog online, evaluasi, Salton \& McGill

\section{ONLINE PUBLIC ACCESS CATALOG EVALUATION USING SALTON AND MCGILL APPROACH}

\begin{abstract}
This study aims to evaluate the library's online catalog of UNY FIP in perspective of management and library users use the approach of Salton and McGill. The research approach used is qualitative, with a type of descriptive-analytical research. The data used are the primary data and secondary data. The results of a study indicates that 1) the value of recall demonstrated numbers $30.61 \%$, while the value of precision showed numbers $75.92 \%$ at subject of child's education, with usage on simple search and advanced search. 2) the system is able to find the needed information within 0.4 seconds. 3) On the point of user effort, there is no special module provided to facilitate users in accessing the online catalog. Especially in the user menu section, where there is no HELP menu, about how to search. The library only provides "Live Chat" and "Ask Librarian" facilities. 4) Display online catalog in accordance with SLiMS Meranti standard. The constraints of the user if the user is not pressing the menu "listing details", then the user will not know the existence of the collection dispersed across three campuses. 5) Collections compiled by the library FIP still dominated by textbooks.
\end{abstract}

Keywords: online catalog, evaluation, Salton \& McGill

\section{PENDAHULUAN}

Kemajuan teknologi dan informasi, saat ini memberikan kemudahan bagi pengguna untuk menemukan informasi yang dibutuhkan darimanapun, kapanpun dan di manapun. Perkembangan teknologi dan informasi juga mempengaruhi cara dalam menangani, memperoleh, dan 
mengelola informasi. Tak dapat dipungkiri hal tersebut membawa imbas di berbagai hal. Antara lain ketersediaan informasi menjadi sangat banyak dan beragam. Informasi menjadi komoditas penting dan menarik. Karena dengan informasi, salah satu manfaatnya dapat mempengaruhi pengambilan keputusan seseorang.

$$
\text { Perkembangan teknologi, }
$$

menyebabkan informasi yang tersedia secara online sangat beragam. Perkembangan ini menimbulkan permasalahan tersendiri bagi pengguna yang belum familiar dengan teknologi internet dan juga kelimpahan informasi.

Kajian mengenai temu kembali informasi telah lama dilakukan. Diketahui sejak tahun 1950, kajian ini dikembangkan dengan meliputi berbagai aspek. Aspek sistem temu kembali informasi dan juga aspek manusia sebagai pengguna sistem tersebut. Sistem Temu Kembali Informasi (STKI) merupakan sistem yang mampu menyimpan, mengambil, dan memelihara informasi. Informasi dalam konteks ini dapat terdiri dari teks (termasuk data numerik dan tanggal), gambar, audio, video dan benda-benda multimedia lain (Kowalski \& Maybury, 2002; Thakur, Mehrota \& Bansal, 2012). Meskipun informasi hanya berperan sebagai objek namun dalam ranah STKI menjadi sangat beragam. Tipe teks merupakan salah satu tipe data yang sering dipakai untuk pengolahan data secara penuh. Tipe data yang lain diperlakukan sebagai sumbersumber yang sangat informatif, terutama yang terkait dengan pencarian berdasarkan teks. Dan teknik ini juga digunakan untuk pencarian jenis media lain.

STKI merupakan sebuah program komputer yang memfasilitasi pengguna dalam mencari suatu informasi yang mereka butuhkan. Sistem ini membutuhkan komputer dengan program standar yang dapat mendukung kerja sistem. Pengukuran kesuksesan sistem informasi melalui sebuah parameter; yakni seberapa cepat dan akurat STKI menemukan informasi yang mereka butuhkan. Cepat dan akurat dalam persfektif pengguna adalah waktu yang dibutuhkan untuk menampilkan informasi yang dibutuhkan, di luar waktu yang dibutuhkan untuk membaca data informasi yang tertampil di laman. Kecepatan dan keakuratan yang lain meliputi komposisi pencarian, eksekusi pencarian, dan pembacaan item non-relevan semua aspek informasi (Kowalski \& Maybury, 2002).

Pengukuran STKI dikenal salah satunya dengan cara mengevaluasi STKI. Mengevaluasi STKI menggunakan dua pendekatan managerial, yaitu membahas sisi STKI dalam pandangan manajemen perpustakaan, dan pendekatan pengguna perpustakaan. Ada beberapa metode dari para pakar yang dipakai untuk mengevaluasi STKI, sebut saja Lancaster, Cleverdon, Vickery, dan Salton and McGill. Mengevaluasi STKI merupakan topik menarik karena dalam mengevaluasi STKI akan muncul berbagai macam area yang akan dikaji. Meliputi perilaku pencarian informasi pengguna melalui antarmuka STKI, penggunaan kata secara kontekstual dalam ranah yang lebih luas, efisiensi penggunaan perangkat komputer, pembiayaan, dan sumber informasi yang dihimpun oleh mesin pencari. Sedangkan fokus utama dari STKI adalah pengukuran efektivitas pengoperasian STKI; penentuan item yang relevan dengan pencarian; penemuan kembali informasi oleh sistem yang relatif dengan kebutuhan informasi pengguna (Sanderson, 2010).

Sedangkan tujuan evaluasi seperti yang disampaikan Swanson adalah sebagai berikut (Chowdhury, 1999): a) untuk menilai tujuan dan rencana program sebelum melaksanakan program tersebut; b) untuk menentukan seberapa baik kinerja tujuan atau harapan yang diinginkan; c) untuk menentukan alasan atau penyebab dari keberhasilan maupun kegagalan program tersebut; d) untuk mengungkap prinsip-prinsip yang mendasari suatu program yang berhasil; e) untuk mengeksplorasi teknik yang dapat meningkatkan efektivitas program; f) untuk memperbaiki cara yang digunakan untuk mencapai tujuan. 
Perpustakaan FIP UNY menggunakan SLiMS sebagai sistem temu kembali informasinya. Hal tersebut memberikan kemudahan pada pengguna perpustakaan FIP yang tersebar di tiga kampus. Yaitu perpustakaan Kampus 1 Karangmalang, perpustakaan Kampus 2 Jalan Kenari, dan perpustakaan Kampus 3 Jalan Bantul. Lokasi perpustakaan ini dicantumkan pada keterangan ketersediaan koleksi yang ada di katalog online Perpustakaan FIP UNY. Termasuk koleksi yang berada di Laboratorium Bimbingan dan Konseling, juga menjadi satu data pada SLiMS Perpustakaan FIP. Namun, sejauh ini belum ada evaluasi terkait penggunaannya. Sehingga kajian ini diharapkan dapat menjelaskan mengenai katalog online FIP UNY dalam perspektif manajemen dan pengguna perpustakaan menggunakan pendekatan evaluasi dari Salton and McGill.

\section{Evaluasi STKI "SALTON AND McGILL"}

Salton and McGill mempunyai teori sendiri dalam melakukan evaluasi terhadap Sistem Temu Kembali Informasi. Evaluasi tersebut terurai dalam beberapa poin, seperti Recall and Precision; Respon Waktu; Upaya Pengguna; Segi Penyajian; dan Cakupan Koleksi. Pada tabel 1 berikut, dapat dilihat evaluasi informasi menurut Salton dan McGill (Chowdhury, 1999).

Di bawah ini akan dibahas satu per satu.

\section{Recall and Precision}

Salah satu penerapan prinsip relevansi yang sejak dahulu digunakan dalam pengembangan sistem information retrieval (IR) adalah penggunaan ukuran recall and precision. Recall adalah proporsi jumlah dokumen yang dapat ditemukankembali oleh sebuah proses pencarian di sistem IR. Lalu precision adalah proporsi jumlah dokumen yang ditemukan dan dianggap relevan untuk kebutuhan si pencari informasi. Rumus untuk mengetahui jumlah recall and precision menurut Salton and McGill sebagai berikut:
Recall=

jmlh item yg relevan diperoleh dr sistem $\mathrm{x} 100 \%$

jmlh koleksi yg dimiliki oleh

perpustakaan ......1

Precision=

jmlh item relevan yg ditemukan di rak $\mathrm{x}$ $100 \%$

jumlah item yang relevan diperoleh dari sistem ...2

Kedua ukuran di atas biasanya diberi nilai dalam bentuk persentase, 1 sampai $100 \%$. Sebuah sistem informasi akan dianggap baik jika tingkat recall maupun precision-nya tinggi. Jika ada seseorang mencari dokumen tentang "Pangeran Diponegoro" pada sebuah sistem, dan jika sistem tersebut memiliki 100 buku tentang Pangeran Diponegoro, maka kinerja terbaik adalah jika sistem tersebut berhasil menemukan 100 dokumen tentang Pangeran Diponegoro.

Tabel 1. Kriteria Evaluasi

\begin{tabular}{ll}
\hline $\begin{array}{c}\text { Kriteria } \\
\text { evaluasi }\end{array}$ & \multicolumn{1}{c}{ Parameter sistem } \\
\hline $\begin{array}{l}\text { Recall and } \\
\text { precision }\end{array}$ & $\begin{array}{l}\text { Indeks exhaustivity } \\
\text { Istilah indeks yang } \\
\text { mendalam dapat meningkatkan }\end{array}$ \\
& recall. \\
& - Term spesifitas \\
& Istilah indeks yang \\
& khusus yang dapat \\
& meningkatkan nilai precision. \\
& Bahasa pengindeksan \\
& menyediakan langkah-langkah \\
& untuk pengenalan sinonim, \\
& istilah-istilah yang terkait yang \\
& meningkatkan recall. \\
- Perumusan permintaan & Kemampuan untuk merumuskan \\
& permintaan pencarian yang \\
akurat. & Strategi pencarian \\
Kemampuan pengguna & untuk merumuskan strategi \\
pencarian yang memadai.
\end{tabular}




\begin{tabular}{|c|c|}
\hline $\begin{array}{l}\text { Kriteria } \\
\text { evaluasi }\end{array}$ & Parameter sistem \\
\hline $\begin{array}{l}\text { Respon } \\
\text { waktu }\end{array}$ & $\begin{array}{l}\text { - Pengorganisasian dokumen } \\
\text { yang tersedia } \\
\text { - Jenis query } \\
\text { - Lokasi pusat informasi } \\
\text { - Frekuensi yang menerima } \\
\text { permintaan pengguna } \\
\text { - Ukuran koleksi }\end{array}$ \\
\hline Upaya & - Aksesibilitas sistem \\
\hline Pengguna & $\begin{array}{l}\text { - Sistem menyediakan } \\
\text { pedoman cara } \\
\text { menggunakannya. } \\
\text { - Fasilitas untuk berinteraksi } \\
\text { dengan sistem }\end{array}$ \\
\hline $\begin{array}{l}\text { Dari segi } \\
\text { penyajian }\end{array}$ & $\begin{array}{l}\text { - Sifat output : referensi } \\
\text { bibliografi, abstrak atau fulltext }\end{array}$ \\
\hline $\begin{array}{l}\text { Cakupan } \\
\text { koleksi }\end{array}$ & $\begin{array}{ll}\text { - } & \text { Jenis perangkat input dan } \\
& \text { ukuran perangkat penyimpanan } \\
\text { - } & \text { Kedalaman analisis subjek } \\
\text { - } & \text { Sifat permintaan pengguna } \\
\text { - } & \text { Bentuk fisik dokumen } \\
\end{array}$ \\
\hline
\end{tabular}

Kalau sistem tersebut memberikan 100 temuan, dan pada temuan tersebut ada 50 dokumen tentang "Pangeran Diponegoro", maka nilai recall-nya adalah 0,5 (atau 50\%) dan nilai precision-nya juga 0,5. Namun jika sistem tersebut memberikan 1 dokumen saja, dan dokumen tersebut adalah tentang "Pangeran Diponegoro", maka recall-nya bernilai 0,01 dan precision-nya bernilai 1 . Nilai precision yang tinggi ini, sebenarnya terjadi karena sistem memberikan hanya 1 jawaban kepada si pencari informasi. Kalau sistem memberikan 100 dokumen, dan hanya 1 yang relevan, maka nilai recall-nya tetap 0,01 dan precision-nya pun ikut merosot ke 0,01 (Pendit, 2008).

Lewat rumus pada tabel 2 dapat dibayangkan bahwa sebuah sistem harus meningkatkan nilai recall dengan memperbesar nilai a pada rumus di atas (atau nilai hits). Nilai a yang besar ini dapat terjadi jika jumlah dokumen yang diberikan oleh sebuah pencarian juga besar. Semakin besar jumlah dokumen yang diberikan, semakin besar kemungkinan nilai a. Tetapi pada saat yang sama, muncul kemungkinan bahwa nilai b (atau jumlah dokumen yang tidak relevan) juga semakin besar. Ini artinya, nilai precision-nya semakin kecil. Dalam berbagai ekperimen ditemukan kenyataan bahwa nilai recall dan precision ini cenderung berlawanan alias berbanding terbalik. Jika recall tinggi, besar kemungkinan precisionnya rendah.

Tabel 2. Rumus recall and precision

\begin{tabular}{cccc}
\hline & Releva & $\begin{array}{c}\text { Tidak } \\
\text { relevan }\end{array}$ & \\
\hline Ditemuka & $\mathrm{a}$ (hits) & $\mathrm{b}$ (noise) & $\mathrm{a}+\mathrm{b}$ \\
$\mathrm{n}$ & & & \\
Tidak & $\mathrm{c}$ & $\mathrm{d}$ & $\mathrm{c}+\mathrm{d}$ \\
ditemuka & (misse & (rejected & \\
$\mathrm{n}$ & $\mathrm{s})$ & ) & \\
Total & $\mathrm{a}+\mathrm{b}$ & $\mathrm{c}+\mathrm{d}$ & $\mathrm{a}+\mathrm{b}+\mathrm{c}+\mathrm{d}$ \\
\hline
\end{tabular}

Lalu berdasarkan tabel tersebut, rumus recall-precision pun menjadi :

Recall $=[a /(a+c)] \times 100 \ldots . .3$

Precision $\quad=[\mathrm{a} /(\mathrm{a}+\mathrm{b})] \times 100 \ldots \ldots 4$

Ukuran recall-precision ini juga sangat bergantung pada apa yang sesungguhnya dimaksud dengan "dokumen yang relevan" itu dan bagaimana memastikan relevan-tidaknya sebuah dokumen. Salah satu kritik terhadap prinsip recall-precision ini menyatakan bahwa ukuran ideal sebuah sistem selama ini terlalu berpihak kepada mesin dan logika yang terlalu ketat. Sangatlah sulit mencapai tingkat recall-precision yang ideal karena keduanya berdasarkan pada ukuran relevansi yang amat lentur dan dinamis.

Selain itu, seorang pencari informasi seringkali tidak hanya peduli pada relevansi, melainkan juga pada banyak hal lain, seperti kecepatan proses pencarian, kemudahan dalam mengajukan permintaan informasi, kenyamanan dalam memandang layar komputer, dan sebagainya. Seringkali seorang pencari informasi rela mengorbankan tingkat precision, asalkan sistem yang dipakainya memberikan respon yang cepat (Pendit, 2008). 
2. Response Time

Efektivitas informasi yang ditemukan, secara langsung dipengaruhi oleh pengguna atau pencari informasi tersebut maupun logika penemuan dokumen yang digunakan oleh sebuah STKI. Pencari informasi kadang harus menerjemahkan informasi yang dibutuhkan ke dalam bahasa yang sesuai dengan disediakan oleh sistem. Dalam sistem temu kembali informasi, secara umum terdapat kata kunci yang sesuai dengan bahasa semantik di mana informasi tersebut dibutuhkan.

\section{Upaya Pengguna}

Pengguna adalah pemeran utama atau pemegang kendali seluruh proses STKI, sehingga kajian evaluasi STKI menggunakan pendekatan sisi pengguna sangat dianjurkan oleh para pakar. Dalam STKI terdapat beberapa jenis pengguna, yaitu: a) Actual Users/real users: merupakan pengguna yang sesungguhnya dalam STKI; b) Potential Users: potensi pada target pengguna STKI; c) Ecpected Users: adalah orang-orang yang diharapkan menggunakan STKI; d) Beneficaly Users: merupakan pengguna yang mendapatkan keuntungan dari STKI yang dipergunakan olehnya; dan e) End Users: menggambarkan siapa yang dituju oleh pengembang STKI, "end" menunjukkah bahwa STKI melibatkan sebuah rantai produksi (Kurniasih, 2014).

Selain jenis pengguna, user-oriented system juga memperhatikan kemampuan pengguna dalam berinteraksi dengan STKI. Terdapat tiga jenis kemampuan pengguna, yakni pengguna ahli (expert user), pengguna berkemampuan sedang (intermediate user), dan pengguna pemula (novice user). Pengguna ahli memiliki pengetahuan yang lengkap mengenai sistem. Mereka dapat mengorganisasikan materi-materi secara luas, menangkis informasi secara koheren, memandang sistem sebagai seperangkat prosedur, konsep-konsep dan prinsip-prinsip yang saling berhubungan cukup tinggi. Sedangkan intermediate user mengetahui sesuatu tentang sistem namun tidak seluruhnya. Dan pengguna pemula memiliki sedikit pengetahuan atau bahkan tidak memiliki pengetahuan sama sekali tentang STKI. Sehingga mereka tidak dapat mengorganisir materi-materi ke dalam struktur yang tepat dan memandang sistem sebagai perangkat program yang tidak dapat diubah lagi (Kurniasih, 2014).

Evaluasi STKI dengan menggunakan pendekatan aksesibilitas merupakan evaluasi pada level tertinggi, di mana pendekatan ini memfokuskan pada aksesibilitas STKI dalam menyediakan dokumen untuk ditemukan kembali. Aksesibilitas merupakan konsep yang abstrak yang didesain untuk mengukur potensi yang dapat dimunculkan pada saat berinteraksi dengan sumber informasi, dan bagaimana sistem akses informasinya. Misalnya bagaimana pengguna dapat mengakses informasi dalam sebuah koleksi, seperti bagaimana mekanisme query nya, mekanisme penelusurannya dan lain-lain (Azzopardi \& Vinay, 2008). Secara ringkas aksesibilitas memandang STKI dalam sudut pandang yang lain dan hal ini berhubungan dengan efektivitas dan efisiensi penggunaan STKI.

Aksesibilitas pada STKI fokus pada pembatasan secara fisik dan virtual komponen STKI yang meliputi pengindeksan dan pengambilan informasi, meskipun terdapat gangguan dari segi fisik (komputer), akses terbatas karena adanya masalah keamanan data, atau ketidakmampuan untuk mendesain web (Azzopardi \& Vinay, 2008). Azzopardi dan Vinay (2008) mendefinisikan konsep aksesibilitas sistem sebagai berikut: a) Dokumen tidak dapat diakses oleh pengguna atau sistem, karena keterbatasan secara fisik atau kondisi virtual sistem; b) "searchability" sebuah laman dipengaruhi oleh seberapa mudah laman tersebut dapat dilihat dan dan seberapa tepat kecocokan item yang ditemukan pada mesin pencari di laman tersebut dan berapa rangking penemuan informasinya; dan c) Bagaimana dokumen tersebut dapat diakses dari sistem 
pengindeksan pada proses temu kembali informasinya.

\section{Cakupan koleksi}

Cakupan koleksi memuat tentang jenis perangkat yang digunakan, analisis subjeknya, bagaimana permintaan pengguna serta bentuk fisik dokumennya.

\section{Katalog Online Perpustakaan FIP UNY} Perpustakaan FIP UNY menggunakan SLiMS Meranti 5 sebagai katalog online-nya. SLiMS Meranti 5 ini merupakan edisi kelima dari varian produk Senayan Library Management System yang dikembangkan oleh Perpustakaan Depdiknas dan dikenal dengan Senayan. Senayan merupakan salah satu OSS berbasis web yang dapat digunakan sebagai perangkat lunak untuk membangun otomasi perpustakaan dalam sistem jaringan komputer atau internet. Perangkat lunak berbasis web sesuai dengan kebutuhan perpustakaan karena aplikasi jenis ini memungkinkan perpustakaan mendekatkan berbagai produk layanannya dengan pengguna perpustakaan. Sehingga pengguna tidak harus datang ke perpustakaan untuk mengetahui jenis layanan dan ketersediaan koleksi yang dimiliki oleh perpustakaan.

Universitas Negeri Yogyakarta menambah modul layanan berdasarkan modul standar dari SLiMS Senayan ini, namun tetap mendukung pelaksanaan modul standar yaitu bibliografi, sirkulasi, keanggotaan, katalog online atau OPAC (online public access catalog), stocktake (penyiangan), master file, system, menu pengolah koleksi terbitan berkala dan multimedia.

SLiMS memiliki beragam macam fitur yang sangat membantu pustakawan, fitur-fitur tersebut adalah: a) pengatalogan (cataloging); b) penelusuran katalog online; c) sirkulasi; d) manajemen perpustakaan; e) inventarisasi koleksi; f) statistik/pelaporan; dan g) manajemen terbitan berseri.

\section{METODE}

Pendekatan penelitian yang digunakan adalah kuliatatif. Sedangkan jenisnya adalah penelitian jenis deskriptifanalitis. Di mana penelitian ini mendiskripsikan dan menggambarkan kondisi lapangan apa adanya (Sugiyono, 2015).

Data yang dikumpulkan terdiri dari data primer dan data sekunder. Data primer didapatkan dari observasi dengan melakukan pengamatan langsung di Perpustakaan FIP UNY, kemudian wawancara dengan pengguna perpustakaan dan pustakawan, lalu melakukan dokumentasi hasil kerja. Yaitu mempelajari dokumen yang berisi informasi SLiMS Perpustakaan FIP. Sedangkan data sekunder adalah data yang berasal dari sumber kepustakaan, yang merupakan literatur, buku catatan, buku panduan dan artikel lain yang berkaitan dengan masalah yang diteliti.

\section{HASIL DAN PEMBAHASAN}

\section{Recall dan Precision}

Berdasarkan wawancara dengan pengguna perpustakaan FIP UNY, katalog online membantu proses penelusuran informasi, namun kadang informasi pada katalog online tidak sesuai dengan keinginan pengguna tersebut. Hal ini dapat terjadi karena kata kunci yang dimasukkan ke katalog online kurang tepat. Dengan demikian informasi dibutuhkan pada katalog online tidak tertampil dan apabila informasi tersebut ditampilkan, kadang kala kurang relevan.

Biasanya pengguna menelusur menggunakan katalog online, memakai simple research karena menurutnya simple research ini dapat menerima kata kunci apa saja yang diinginkan. Tetapi di sisi lain, fasilitas simple research akan menghasilkan jumlah recall yang tinggi dan precission yang rendah sehingga menghambat pengguna dalam mencari dokumen yang diinginkan. Penulis mencoba mengukur keefektifan dari dua sarana penelusuran tersebut (simple search 
dan advanced search) berdasarkan subyek "pendidikan anak". Dan berikut hasilnya:

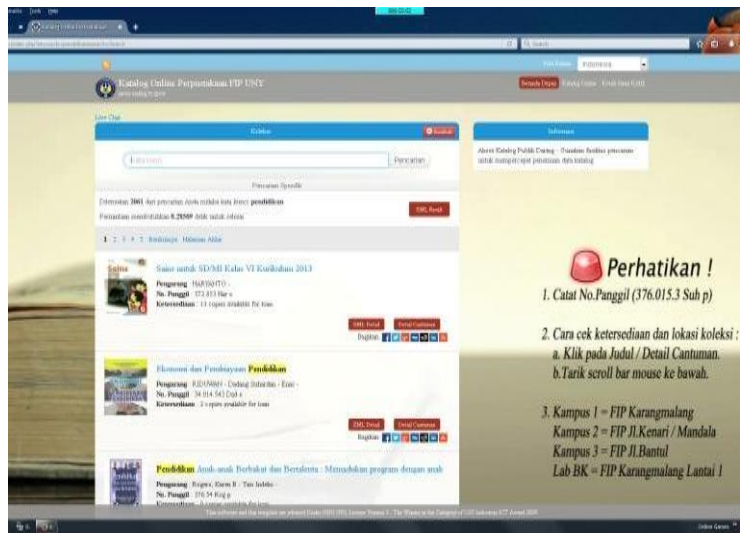

Gambar 1. Hasil Recall dan Precion

$$
\begin{aligned}
\text { Recall } & =\frac{2679}{8750} \times 100 \% \\
& =30.61 \%
\end{aligned}
$$

Recall dengan kata kunci "Pendidikan Anak" adalah 30.61\%. Sedangkan Presisi dihitung dengan menggunakan rumus 2 , maka didapat perhitungan seperti di bawah ini:

Presisi

$$
\begin{aligned}
& =\frac{2034}{2679} \times 100 \% \\
& =75.92 \%
\end{aligned}
$$

Presisi yang ditemukan dari kata kunci "Pendidikan Anak" adalah 75.92\%.

\section{Waktu Respon}

Menurut pustakawan di Perpustakaan FIP UNY waktu respon dalam penelusuran informasi menggunakan katalog online di SliMS hasilnya sudah sangat baik, karena rata-rata waktu respon yang ditampilkan di katalog online sekitar 0,4 detik. Dan katalog online itu sendiri menampilkan waktu respon penelusuran sehingga penelusur bisa mengetahui beberapa lama waktu yang dibutuhkan oleh sistem untuk menampilkan informasi yang ditelusur.

Sedangkan menurut pengguna waktu respon ini tergantung dengan banyaknya data koleksi yang keluar dari katalog online jika data buku yang keluar banyak maka waktu yang diperlukan untuk menampilkan menjadi lebih lama dan waktu respon, sudah ditampilkan di katalog online. Dan pengguna biasanya butuh waktu sekitar 15 menit untuk mencari dokumen di rak sampai buku bisa ditemukan.

Advanced Search lebih memberikan waktu yang lebih cepat dalam menampilkan hasil yang diinginkan daripada simple search.

\section{Upaya Pengguna}

Pada bagian upaya pengguna beberapa hal yang dijadikan pegangan adalah Aksesibilitas sistem. Sistem menyediakan pedoman cara menggunakannya dan fasilitas untuk berinteraksi dengan sistem, dan juga terkait dengan hal-hal apa saja yang dapat dilakukan oleh pengguna dalam proses penelusuran. Laman bagian depan SLiMS Perpustakaan FIP UNY, sudah dimodifikasi, sehingga tampilannya menjadi seperti pada gambar 2. Dan gambar 3 menampilkan katalog online perpustakaan.

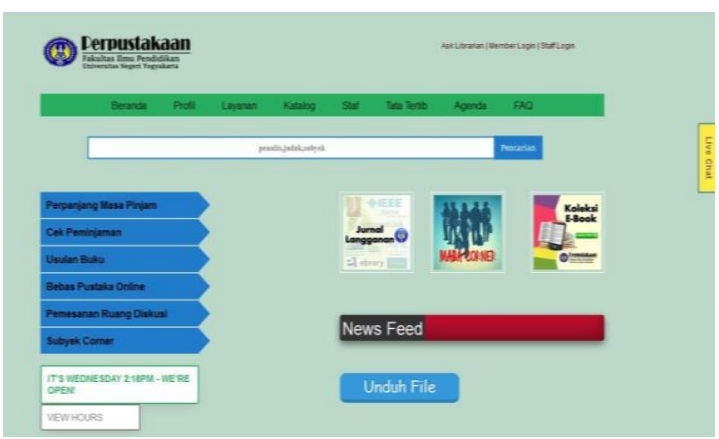

Gambar 2. Tampilan Laman Perpustakaan

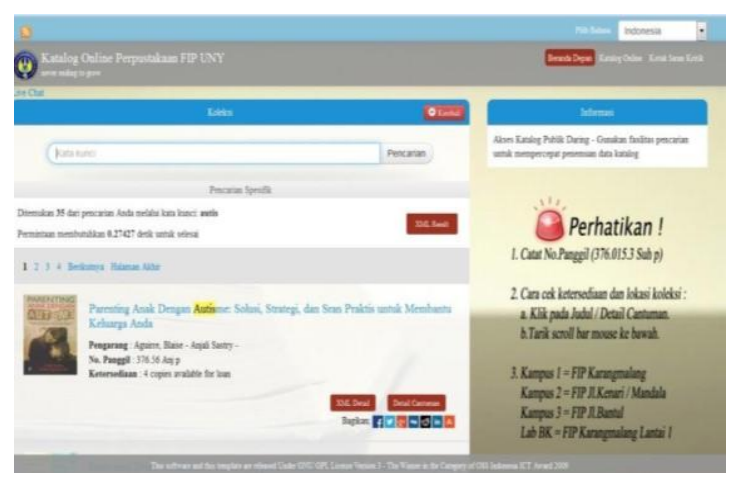

Gambar 3. Tampilan Katalog Online Perpustakaan $(O P A C)$ 
Salah satu evaluasi berdasarkan upaya pengguna adalah apakah sistem menyediakan pedoman cara menggunakannya atau kah tidak, serta fasilitas apa yang disediakan bagi pengguna untuk berinteraksi dengan sistem.

Laman library.fip.uny.ac.id dapat diakses dari dalam maupun luar lingkungan UNY, sehingga pengguna dapat mencari koleksi yang diinginkan melalui laman tersebut di manapun dan kapanpun. katalog online Perpustakaan FIP pada laman "beranda" menyediakan "Penelusuran Sederhana" (simple search) seperti terlihat pada Gambar 2. Sedangkan pada laman katalog online terdapat menu "Pencarian Spesifik", seperti terlihat pada Gambar 4. Dan ketika pengguna selesai mengetikkan kata pada kotak penelusuran, katalog online Perpustakaan FIP UNY menerima perintah dengan mengklik tombol "enter" maupun mengklik pada tombol "Pencarian".

Pada gambar 2 dapat dilihat bahwa laman library.fip.uny.ac.id menyediakan kotak pencarian, dan di bagian tengahtengah kotak dituliskan kata-kata "penulis, judul, subyek". Untuk pencarian menggunakan "pencarian sederhana" pengguna dapat menggunakan semua jenis kata kunci sesuai keinginan pengguna, sehingga ada beberapa kata yang ditampilkan dan tidak sesuai/tidak relevan dengan keinginan pengguna. Hal ini menjadi salah satu item penghambat dalam penelusuran.

Sedangkan dalam menu "pencarian spesifik", katalog online SLiMS menyediakan tambahan pilihan yaitu: kolom Pengarang; kolom Subjek; kolom ISBN/ISSN; kolom GMD (yang berisi semua bentuk media yang dapat disajikan di katalog online, seperti CD-ROM, Filmstrip, Manuscript, Text, dan lain-lain); kolom Tipe Koleksi (berisi keterangan tentang koleksi berjenis Fiksi, Reference, dan Textbook); kolom Lokasi (terdapat 4 lokasi, Kampus 1, 2, 3 dan Lab. BK), seperti terlihat pada gambar 4 .

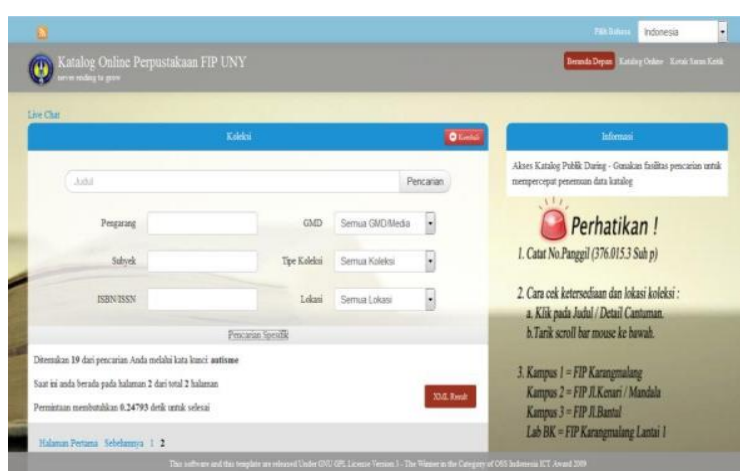

Gambar 4. Tampilan Katalog Online Perpustakaan Menu Pencarian Spesifik

Dengan komponen yang seperti terlihat pada gambar 5 .

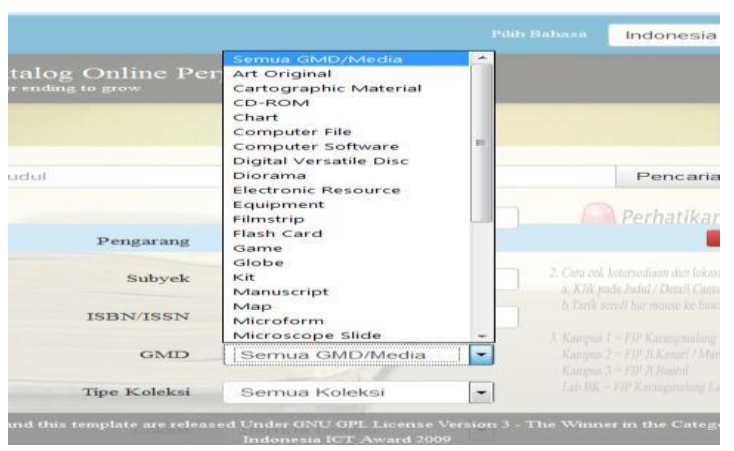

Gambar 5. Tampilan Katalog Online

Perpustakaan Menu Pencarian Spesifik

Berikut akan disimulasikan pencarian melalui katalog online Perpustakaan FIP UNY, pada menu Pencarian Sederhana dan Spesifik, menggunakan Kata Kunci dengan kata "Pendidikan Anak". Pada gambar 6, kata "Pendidikan Anak" yang dicari melalui Pencarian Sederhana menghasilkan 150 hasil.

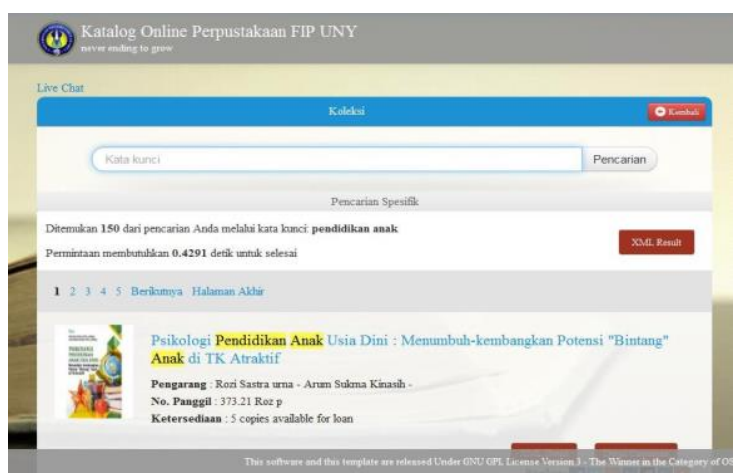

Gambar 6. Hasil Pencarian Sederhana

Semua kata yang memuat kata "Pendidikan Anak" ditampilkan oleh 
katalog online SLiMS. Dalam katalog online ditandai dengan pemberian blok kuning pada kata yang dimaksud. Dengan memunculkan semua kata yang mengandung kata kunci pengguna masih harus memilah-milah judul buku mana sajakah yang sesuai dengan kebutuhannya. Inilah yang dimaksud dengan hambatan pencarian.

Sedangkan untuk pencarian menggunakan menu "Pencarian Spesifik" dapat dilihat pada gambar 7. Pada gambar 7 terlihat, menggunakan kata kunci "Pendidikan Anak", lalu subjek yang dicari juga "Pendidikan Anak" dengan pilihan GMD nya "teks", pada semua koleksi baik fiksi, referensi maupun teksbook, dan di lokasi manapun, ditemukan sebanyak 15 buah hasil.

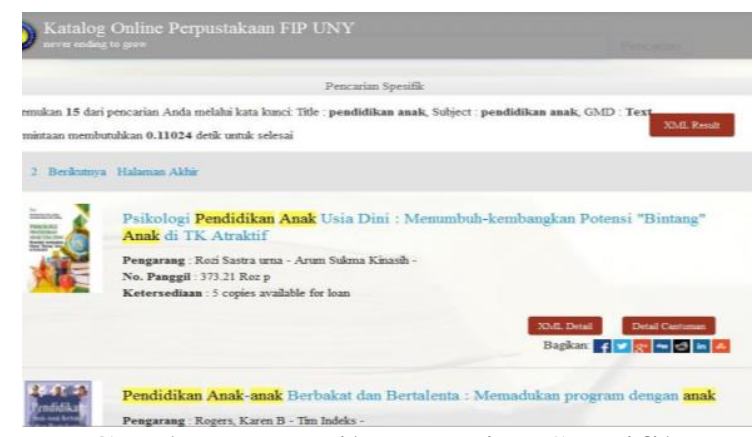

Gambar 7. Hasil Pencarian Spesifik

Berkaitan dengan pedoman, walaupun sudah menambahkan satu halaman sebelum katalog online Perpustakaan, namun nyatanya masih belum ada informasi yang disediakan oleh pustakawan dalam membantu pengguna melakukan pencarian. Langkah-langkah apa saja yang seharusnya dilakukan oleh pengguna dalam melakukan pencarian belum ditampilkan pada laman katalog online Perpustakaan FIP UNY. Sehingga ketika pengguna mengalami kendala pencarian, laman katalog online tidak dapat memberikan informasi tentang langkah apa yang sebaiknya dilakukan oleh pengguna untuk tetap dapat melakukan penelusuran.

Namun di sisi lain, katalog online Perpustakaan FIP UNY menyediakan fasilitas "Live Chat" dan "Ask Librarian" yang diperuntukkan bagi pengguna untuk bertanya kepada pustakawan jika mengalami kesulitan pencarian. Pada sisi kanan layar background terdapat informasi yang diperuntukkan bagi pengguna, apa saja yang perlu diperhatikan oleh pengguna ketika melakukan pencarian menggunakan katalog online Perpustakaan FIP UNY.

\section{Segi Penyajian (Tampilan)}

Tampilan katalog online

Perpustakaan FIP telah dirubah dari template bawaan SLiMS Meranti, masih sederhana namun sudah berisi beberapa informasi yang diperuntukkan bagi mahasiswa. Menurut mahasiswa tampilan beranda sangat sederhana namun sudah komunikatif. Hal yang kadangkala masih membuat bingung mahasiswa adalah poin "Ketersediaan". Apabila pengguna tidak meng-klik detil cantuman pada koleksi yang dikehendaki, maka pengguna tidak akan mengetahui di manakah koleksi tersebut berada.

Sedangkan, pada tampilan bibliografi selain informasi umum yang memuat judul buku, keterangan kepengarangan, impresum, deskripsi fisik dan juga ketersediaan koleksi serta keterangan tersedia ataupun sedang dipinjam, juga terdapat cover buku, abstrak buku, dan pada beberapa koleksi terdapat lampiran daftar isi.

\section{Cakupan Koleksi}

Subjek yang dimasukkan ke dalam bibliografi SLiMS belum terstruktur dengan baik. Ada beberapa judul sama dengan daftar isi yang hampir sama, namun pemberian subjeknya berbeda.

Sedangkan bentuk fisik dokumen yang dihimpun dalam katalog online ini adalah dalam bentuk teks. Hal tersebut karena buku merupakan bentuk fisik yang masih mendominasi di perpustakaan FIP UNY.

\section{PENUTUP}

$\begin{array}{llrr}\text { Hasil kajian terhadap } & \text { katalog } \\ \text { online perpustakaan } & \text { FIP } & \text { UNY } \\ \text { menunjukkan bahwa } & \text { 1) } & \text { Nilai } & \text { recall }\end{array}$


menunjukkan angka $30.61 \%$, sedangkan nilai precision menunjukkan angka $75.92 \%$ untuk subjek pendidikan anak, dengan penggunaan pada simple search dan advanced search. 2) Sistem mampu menemukan informasi yang dibutuhkan dalam kurun waktu 0,4 detik. 3) Untuk poin upaya pengguna, belum ada modul khusus yang disediakan untuk memudahkan pengguna dalam mengakses katalog online. Terutama pada bagian menu pengguna, di mana belum ada menu HELP, tentang tata cara menelusur. Perpustakaan hanya menyediakan fasilitas "Live Chat" dan "Ask Librarian". 4) Tampilan katalog online sesuai dengan standar SLiMS Meranti. Kendala pengguna adalah apabila pengguna tidak menekan menu "detil cantuman", maka pengguna tidak akan mengetahui keberadaan koleksi yang tersebar di tiga kampus. 5) Koleksi yang dihimpun perpustakaan FIP masih didominasi oleh buku teks.

\section{DAFTAR PUSTAKA}

Azzopardi, L. and Vinay, V. (2008). Accessibility in Information Retrieval. 2008. Diakses dari http://ir.dcs.gla.ac.uk/ leif/papers/az zopardi2008accessibility_short.pdf.

Chowdhury, G.G. (1999). Introduction to Modern Information Retrieval. London: Library Association Publishing.

Kowalski, G. J. \& Maybury, M. T. (2002). Information Storage and Retrieval System: Theory and Implementation, Second Ed. New York: Kluwer Academic Publisher.

Kurniasih, N. (2014). Aspek Pengguna dalam Sistem Temu Kembali Informasi. Diakses dari https://www.academia.edu/6672852/ Aspek_Pengguna_dalam_Sistem_Te mu_Kembali_Informasi.

Pendit, P. L. (2008). Perpustakaan Digital: dari A sampai Z. Jakarta: Cita Karyakarsa Mandiri.

Sanderson, Mark. (2010). Test Collection Based Evaluation of Information
Retrieval System dalam Foundation and Trends in Information Retrieval vol 4 No 4, pp. 250, DOI $10.1561 / 1500000009$.

Sugiyono. (2015). Metode Penelitian Pendidikan: Pendekatan Kuantitatif, Kualitatif, dan $R \& D$. Bandung: Alfabeta.

Thakur, N., Mehrotra, D., and Bansal, A. (2012). Information Retrieval System Assigning Context to Documents by Relevance Feedback dalam International Journal of Computer Application vol 58 (20) Nov 2012, https://pdfs.semanticscholar.org/f174 /45743616076e83c7e8a2669c1eec67 d42a1e.pdf. 